\title{
Controlling beer filtration process through implementation of enzymatic and microbiological techniques
}

\author{
Luljeta Pinguli, Ilirjan Malollari, Rozana Troja, Hasime Manaj and Anisa Dhroso
}

\begin{abstract}
The best practice for filtration optimization process is to control biological and non biological particles at every stage of beer chain production. There are several processes that can be used to control beer filtration process, such as settlement of non-biological and biological particles through sedimentation, centrifugation, extended stabilization periods, addition of flocculants and clarifiers to reduce both, yeast and haze loadings etc. Filtration process is controlled by yeast, proteins and carbohydrates. Cell yeast number in suspension determines which is going to dominate filtration process. If yeast cell number is less than a million, filterability is dependent mainly from physico-chemical beer characteristics, otherwise biological phase control filtration process. In this paper we have proposed some enzymatic and yeast management techniques to improve filtration process. Experiments were carried out in laboratory and industrial scale. There were used free and immobilized enzymes and yeast. It was noticed a good correlation between laboratory and industrial application findings. Immobilized yeast in batch processes not only make easier yeast management but also increase beer filterability, excluding some energy consuming processes like centrifugation and long conditioning time.
\end{abstract}

Keywords: Beer filterability, enzymes, haze, yeast, stabilization, immobilization

Department of Industrial Chemistry, Faculty of Natural Sciences, University of Tirana, Tirana, Albania

${ }^{*}$ Corresponding author: L. Pinguli E-mail: luljeta.pinguli@fshn.edu.al DOI: 10.2478/ebtj-2018-0021 (c) 2018 Authors. This work was licensed under the Creative Commons AttributionNonCommercial-NoDerivs 3.0 License.

\section{Introduction}

Filtration is the process of removing suspended particulates from beer. These particulates include Microbiological Particles (MP) that consist on yeast and bacteria and NonMicrobiological Particles (NMP) that covers a multitude of compositional species, although they are generally comprised of protein, usually associated with polyphenols and other molecules such as lipids, carbohydrates, and/or metal ions (1).

The biggest cause of concern, since they are more difficult to remove than yeast, is Non-Microbiological Particles. The biggest amount of NMP are produced and removed at five stages of the brewing process. Better understanding particle formation and removal will allow easily control the process to achieve a consistent and optimum level of beer particles, leading to a more consistent and efficient clarification process $(2,3)$.

There are several processes that can be used to reduce solids loading in the beer, e.g., settlement by gravity or centrifugation (or combination of them), extended lagering periods, addition of flocculants enzymes and clarifiers to reduce both, yeast and haze loadings. It is the duty of a chemical engineer to select and combine all these processes in order to take an optimal beer consistency that will lead in an optimal filtration process $(4,7)$.

\section{Material and Methods}

Experiments were carried out in industrial and experimental scale at "Stefani \& Co" brewery in Tirana, Albania. In experimental scale were used two kinds of different malt. Good 
quality and bad quality malt. At "Stefani \& Co" brewery it is used kieselguhr candle filter. All measurements were carried out for the same beer brand (primitive extract $10.8^{\circ} \mathrm{Ba}$ and fermentationmaturation standard conditions). Testing methods are taken from Analytica EBC and Analytica-EBC Microbiologica. $(5,6)$. The results were statistically analyzed regarding Analitica-EBC, Section 14, Statistics, Method 14.1. Results

\section{Results}

The most important issue of this study is to determine critical parameters that impact on beer filtration and manipulated variables which indicates the manner of intervention in the process. These parameters are summarized in Table 1.

The filterability of a beer was represented by the maximal filtrate volume, $\mathrm{V}_{\max }$ in a given differential pressure (see Fig. 1).

Table 1. The most critical parameters that impact on beer filtration and points where can be intervented in the process

\begin{tabular}{|l|l} 
Critical parameters that impact on beer filtration & Intervention in the process
\end{tabular}

\section{Before Filtration}

Number of yeast cells in the fermentation tank Number of yeast cells in the Bright Beer tank
Controlling yeast number in suspension through different intervention.

Using of flocculants

Using of centrifugation process

Intervention to candle filter process (change kieselguhr dosage and nature)

Wort and Beer Turbidity

Controlling non-biological turbidity through enzymatic processes or different additives.

Wort and Beer Viscosity

Controlling non-biological turbidity through enzymatic processes

\section{During Filtration Process}

Differential pressure on the filter

Intervention to candle filter process (change kieselguhr dosage and nature)

Intervention to beer nature regarding, microbiological load, and non microbiological turbidity (protein, carbohydrates and polyphenols)

Turbidity at filter outlet

Controlling number of yeast and other spoilage microorganisms Recycling

Use of enzymes and different stabilisants

Reorganizations of filter-aid dosage

Microbiologic quality monitoring

Intervention to hygiene measure

Reorganizations of filter-aid dosage

\section{After Filtration}

Turbidity

Use of different stabilisants to control stability

Microbiologic quality monitoring

Intervention to hygiene measure

Reorganizations of filter-aid dosage

Table 2. Nature of Particles in suspension in beer

\begin{tabular}{|c|c|c|c|}
\hline $\begin{array}{l}\text { Nature of particles } \\
\text { in suspension }\end{array}$ & Composition & Source & $\begin{array}{l}\text { Particle size } \\
\text { in } \mu \mathrm{m}\end{array}$ \\
\hline \multirow[t]{2}{*}{ Microorganisms } & $\begin{array}{l}\text { Brewing yeast (Saccharomyces carlsbengensis) + wild yeast } \\
\text { (Saccharomyces sp.) }\end{array}$ & $\begin{array}{l}\text { Fermentation process } \\
+ \text { contamination }\end{array}$ & $5-10 \mu \mathrm{m}$ \\
\hline & Bacteria (Lactobacillus sp., Pediococcus sp.) & Contamination & $0.2-2 \mu \mathrm{m}$ \\
\hline \multirow{2}{*}{ Turbidity } & Carbohydrates turbidity (stable turbidity ) & Brewhouse & \multirow{2}{*}{ Up to $3 \mu \mathrm{m}$} \\
\hline & Proteins and Poliphenols & Brewhouse & \\
\hline
\end{tabular}




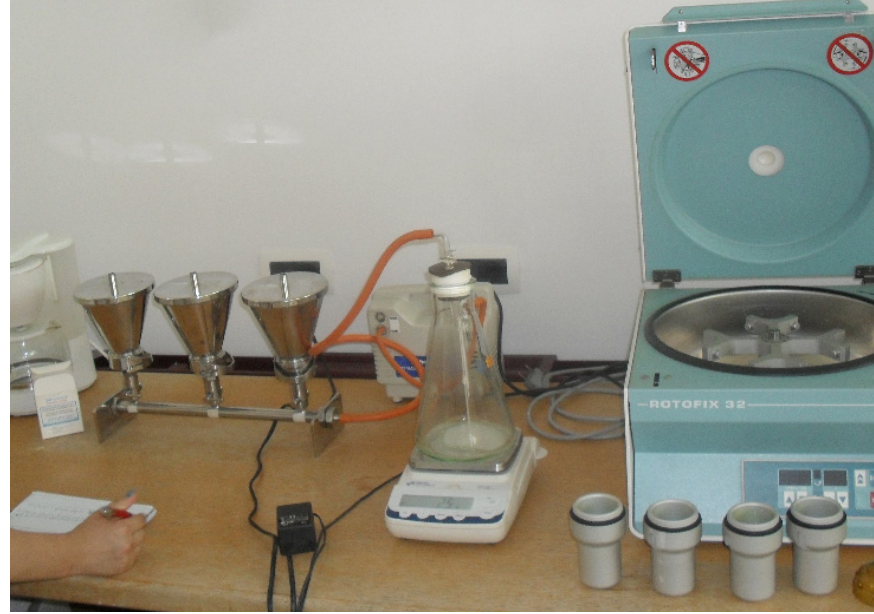

Figure 1. Pilot scale apparatus and centrifuge used for beer filterability monitoring in experimental scale.
- $V_{\text {max }}=321 \mathrm{~g}$ good filtrability (centrifugated beer treated with filter-aids and enzymes)

- $\mathrm{V}_{\max }=116 \mathrm{~g}$ medium filtrability (centrifugated beer without filter-aids and enzymes)

$\Delta \mathrm{V}_{\max }=63 \mathrm{~g}$ bad filtrability (untreated beer)

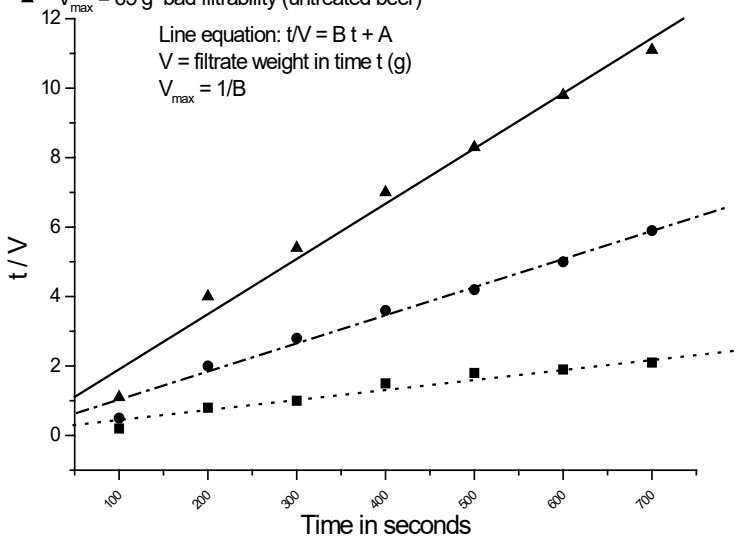

Figure 2. Filtrability of different beers treated and not treated with enzymes.

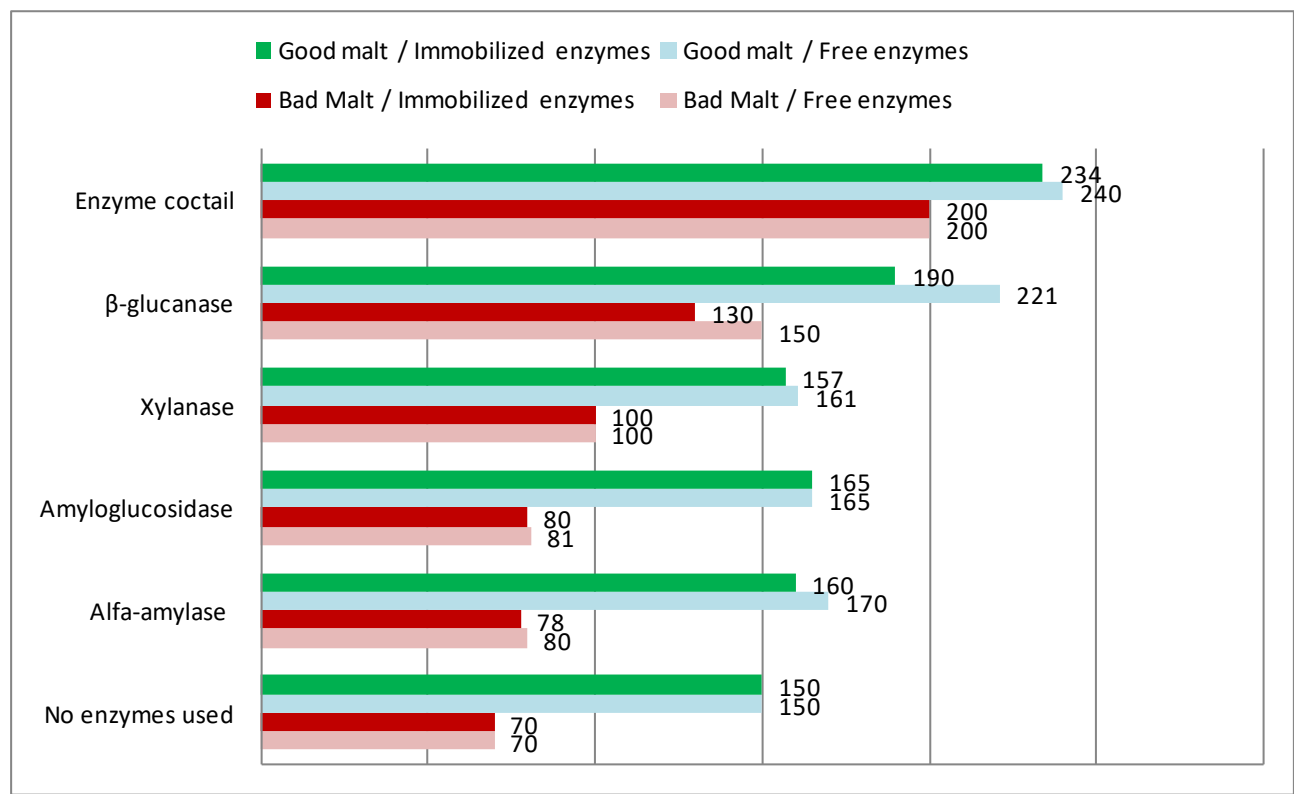

Figure 3. Impact of malt quality and different enzymes used at brewhouse on beer filterability (Vmax).

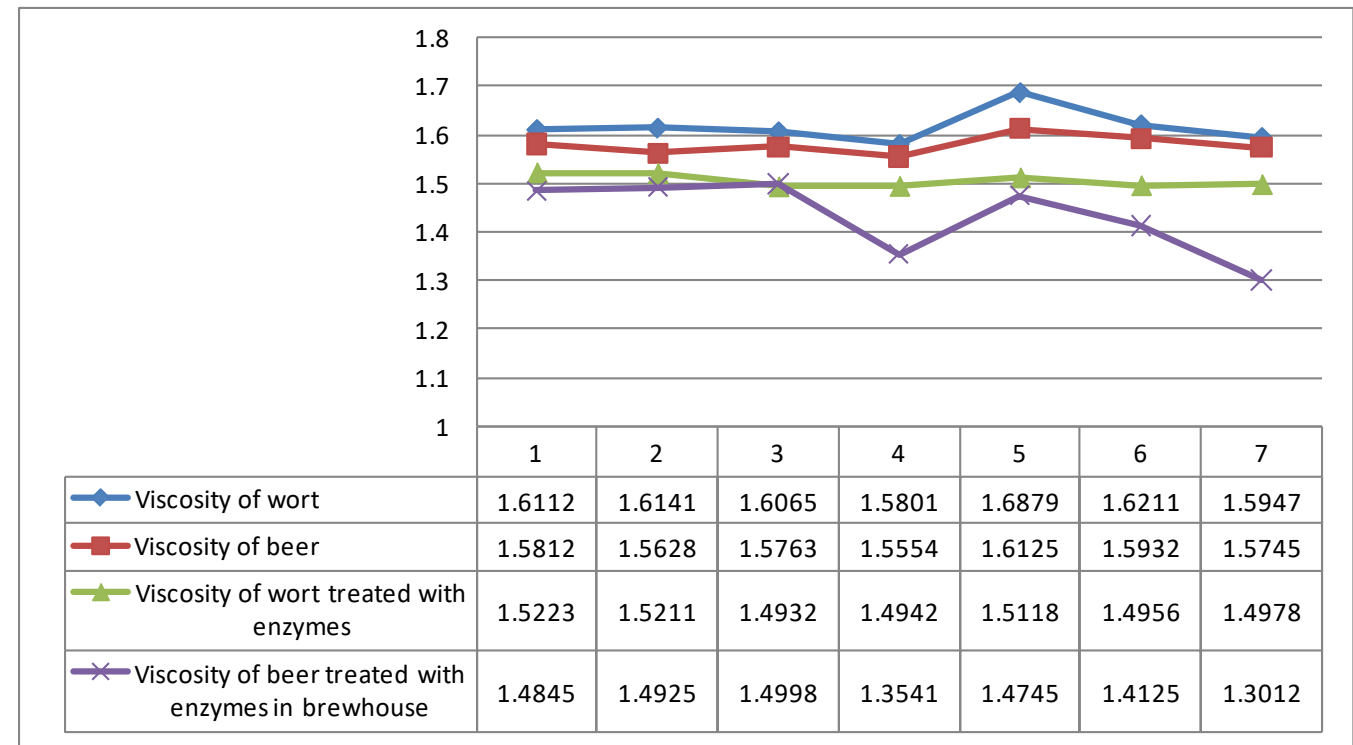

Figure 4. Dynamic Viscosity (mPa s) in worts treated and non treated with enzymes ( $\beta$-glucanase enzyme). 


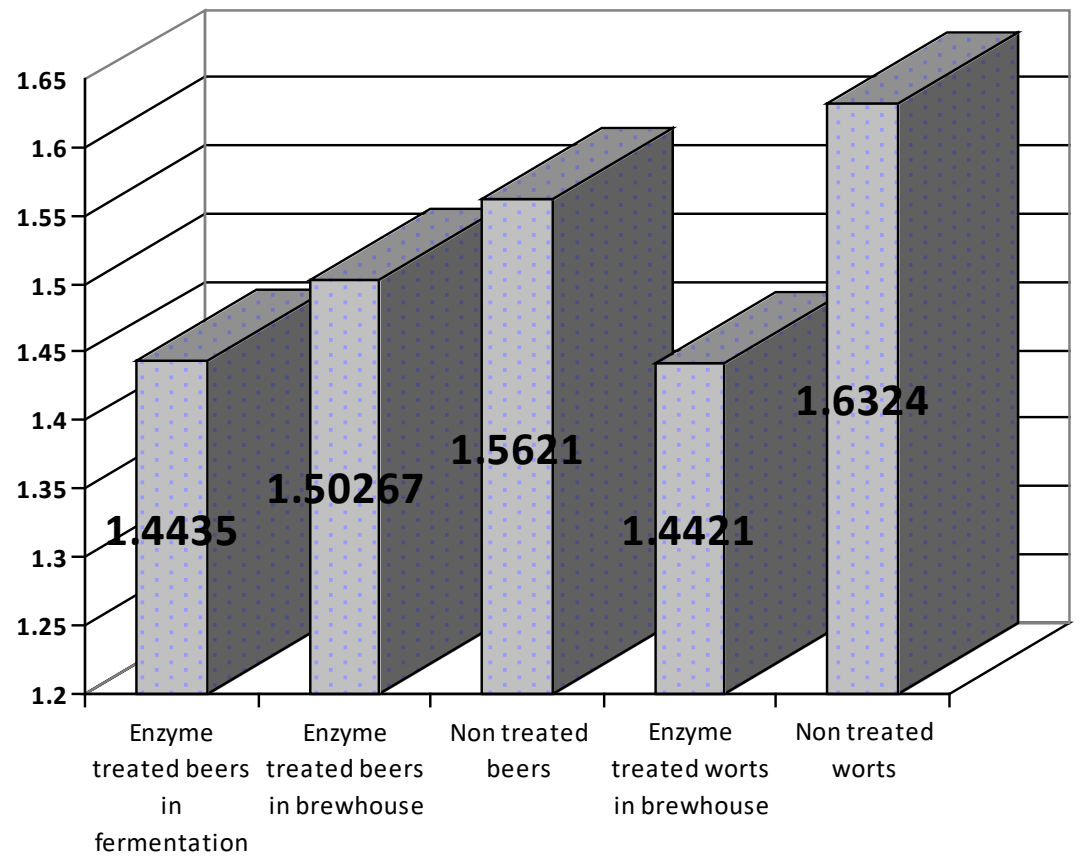

Figure 5. Viscosity in worts and beer treated in different manner with enzymes.

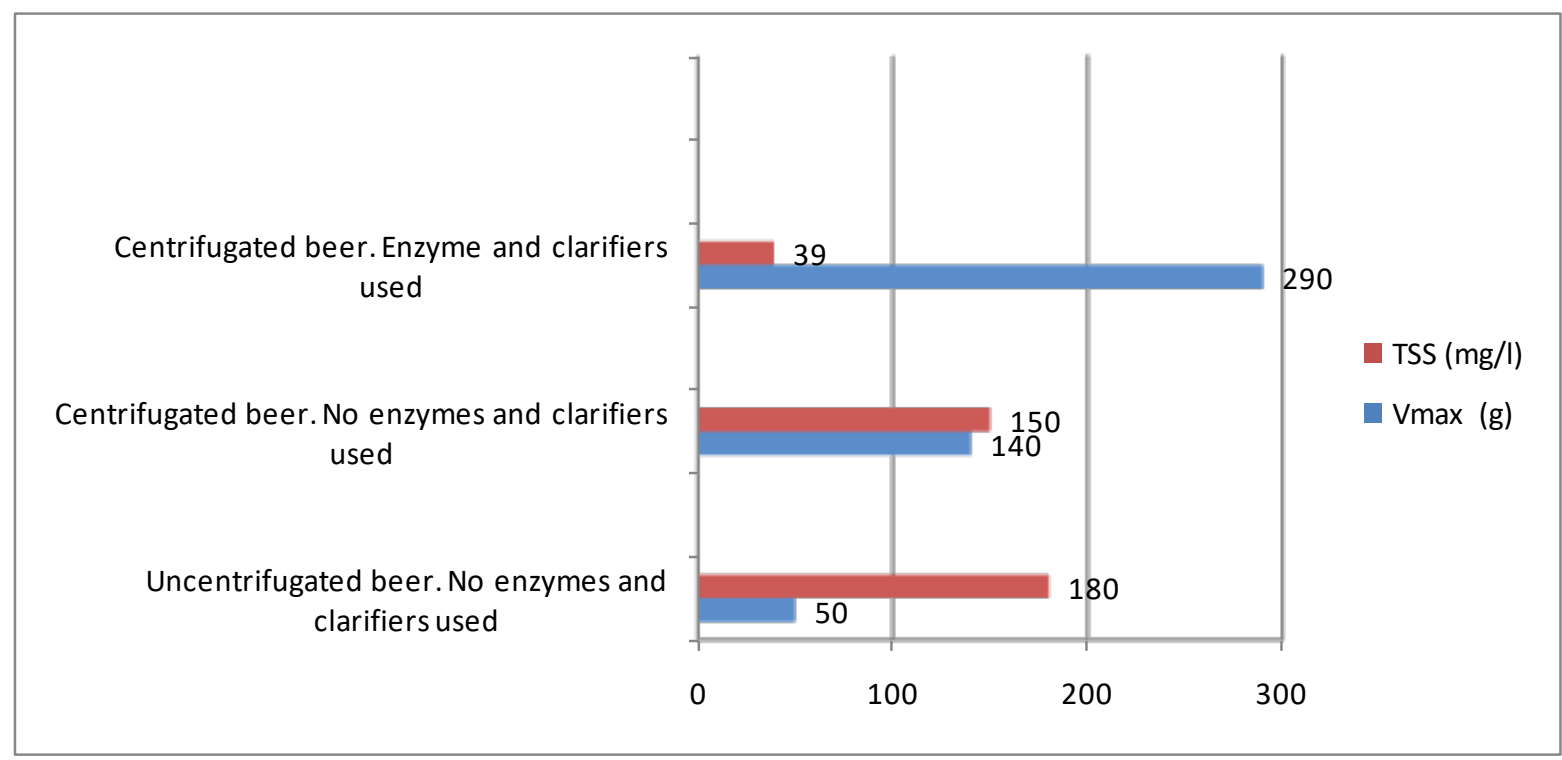

Figure 6. Average Vmax and TSS for different treated beers.

Table 3. Evaluation of most critical stability parameters of beer from fermentation to the Bright Beer Tank (These processes are in chain and experiments were carried out in industrial scale)

\begin{tabular}{|c|c|c|c|c|c|}
\hline & $\begin{array}{c}\text { In the end of } \\
\text { Fermentation }\end{array}$ & $\begin{array}{c}\text { After } \\
\text { centrifugation }\end{array}$ & $\begin{array}{c}\text { After filter aid } \\
\text { tratment }\end{array}$ & $\begin{array}{c}\text { Clarification } \\
\text { process }\end{array}$ & $\begin{array}{c}\text { After kiselguhr } \\
\text { filtration }\end{array}$ \\
\hline $\begin{array}{c}\text { Yeast cell number } \\
\text { cell/ml }\end{array}$ & $5-30 \times 10^{6}$ & $1-10 \times 10^{5}$ & $1-8 \times 10^{5}$ & $1-5 \times 10^{5}$ & $0-10$ \\
\hline Turbidity EBC & 223 & 185 & 210 & 160 & 0.5 \\
\hline Total N mg/l & 90 & 85 & 55 & 43 & 40 \\
\hline Poliphenols mg/l & 23 & 15 & 6 & 5 & 0.8 \\
\hline
\end{tabular}


Table 4. Experimental measurements for cell number using free yeast and immobilized yeast in alginate beads (Using industrial scale wort)

\begin{tabular}{|c|c|c|}
\hline Number of yeast cells in sunspension (cell/ml) & Free yeast fermentation & Immobilized yeast fermentation \\
\hline Inoculation cell number & $10 \times 10^{6}-20 \times 10^{6}$ & $10 \times 10^{6}-20 \times 10^{6}$ \\
\hline $\begin{array}{l}\text { Yeast cell number in the end of fermentation } \\
\text { remain in suspension }\end{array}$ & $25-100 \times 10^{6}$ & $1-70 \times 10^{4}$ \\
\hline $\mathrm{v}_{\max }$ & $10-35$ & $260-330$ \\
\hline TSS (mg/l) & 210 & $50-90$ \\
\hline
\end{tabular}

All the worts for these trials were produced by infusion and the enzymes were used one by one. Wort was produced in pilot scale mashing infusion process.

In the case when yeast cell number is less than $10^{6}$, filterability is dependent only from physico-chemical beer characteristics. In this case (see Table 2) centrifuge has low impact on beer turbidity and filterability too.

\section{Discussions}

Optimization of beer filtration is crucial to keep in control beer microbiology. Mostly after filtration remain yeasts and other contaminant microorganisms that came's from the early stages. Optimization of filtration process is very important to control yeast and contaminant removal after fermentation.

The processes prior to filtration have a significant impact on solids loading on a beer filter. Yeasts dominate beer process filtration if there are up to $10^{6}$ cells $/ \mathrm{ml}$. Beer centrifugation is a very good method for yeast control cell and haze level too, but it is an expensive process and beer risk contamination and oxidation in the same time. Filter-aid treatment and clarification process impact on poliphenols and protein level (NMP haze).

Filtration process is controlled by yeast, proteins and carbohydrates. If yeast cell number is less than a million, filterability is dependent mainly from physico-chemical beer characteristics. Beer filterability is strongly depended by malt quality, especially $\beta$-glucans and gomma content that impact directly on beer viscosity. If beer or wort has a high viscosity it is strongly recommended to use enzymes to control carbohydrates that dominate filtration characteristics such as unmodified starch, dextrins, pentosans, and $\beta$-glucans. Carbohydrates that have a signicative impact on filtration were tested using enzymatic techniques. There were used immobilized and free enzymes.

It is noted that immobilized enzymes in alginate beads has a lower effect when it is used in the same dosage at wort treatment. This can be regulated increasing enzyme concentration in the wort. Immobilization save a lot of money because enzyme can be reused batch after batch so it offer the luxury to use a higher concentration in experimental scale. At industrial scale this process it is not so easy to apply because enzyme recovery it is very difficult to apply because of boiling process. It is recommended to use free enzymes in mashing process and immobilized enzymes during beer treatment in maturation. For example, $\beta$-glucanase enzyme was used in wort and beer during maturation. There were not significative differences between filterability of these beers, but the most important fact was that $\beta$-glucanase enzyme used in brewhouse shortens also the mash filtration time in the lauter tun filter.

When dynamic viscosity is higher than 1.55 it is noticed bad beer filterability. Beer filterability was improved using $\beta$-glucanase enzyme in brewhouse or in fermentation. Using this enzyme in brewhouse is more efficient because in the same time it is improved wort filterability, protein coagulation and it needs less energy for wort boiling. As it is very difficult to use immobilized $\beta$-glucanase enzyme in brewhouse all experiments carried out in industrial scale during mashing process are realized with free enzymes.

Immobilized yeast increase significantly filtration rate. The amount of yeast released in suspension from alginate structure generally was $10^{4}$. After 6 batches the structure releases and the number of cell go around $10^{5}$, because the diameter of immobilized beads increased and structure released more cells in the medium. Entrapment immobilization technique protected the morphology of cells, and supported cells growth and budding. Immobilized yeast is easier to handle than the free cells. In industrial scale from the point of optimization of filtration process this will save a lot of money, reducing energy cost, exluding centrifugation process and operational filter running costs.

\section{Conculusion}

Optimization of beer filtration is crucial to keep in control beer microbiology. The processes prior to filtration have a significant impact on solids loading on a beer filter.

Yeasts dominate beer filtration process if there are up to $10^{6}$ cells $/ \mathrm{ml}$. Beer centrifugation is a very good method for yeast control cell and haze level, but it is an expensive process and beer risks contamination and oxidation in the same time. Immobilized yeast increase significantly filtration rate. The amount of yeast released in suspension from alginate structure generally was $10^{4}$. After 6 batches the structure released and the number of cell in suspension was around $10^{5}$. Immobilized yeast is easier to handle and has a lower contamination risk compared to free cells. In industrial scale from the point of optimization of filtration process this will save a lot of money, 
reducing energy cost, excluding centrifugation process and lowering significantly operational filter running costs.

If yeast cell number is less than a million, filterability is dependent mainly from by malt quality, especially $\beta$-glucans and gomma content that impact directly on beer viscosity. It is noted that immobilized enzymes in alginate beads has a lower effect when it is used in the same dosage at wort treatment. Immobilization save a lot of money because enzyme can be reused batch after batch so it offer the luxury to use a higher concentration in experimental scale. It is recommended to use free enzymes in mashing process and immobilized enzymes during beer treatment in fermentation.

\section{Conflict of interest statement}

The authors declare that they have no conflict of interest.

\section{References}

1. Bamforth C. Beer Haze. Journal of the American Society of Brewing Chemists, (1999). 57(3), 81-90.

2. European Brewery Convection. Manual of Good Practice. Beer Filtration, Stabilization and Steilization, (1999), 110-156.

3. European Brewery Convection. Manual of Good Practice. Fermentation \& Maturation, 2000, 120-187.

4. Ian L. Ward. Wort and Beer Clarification Manual, 20-53.

5. European Brewing Chemists: Analytica EBC; Methods of Analysis, (1992).

6. Europian Brewing Chemists: Analytica-EBC Microbiologica.

7. Speers RA., Tung MA, Durance TD, Stewart GG. Colloidal aspects of yeast flocculation: a review. J Inst Brew.1992, 98, 525-531.

8. Stratford M, Carter AT, Yeast flocculation: Lectin synthesis and activation. Yeast, 1993, 9, 371-378.

9. Straver MH, Kijne, JW, Smit G. Cause and control of flocculation in yeast. Trends Biotechnol. 1993, 11, 228-232. 